\title{
$\mathrm{BIM}$ 기반의 설계를 위한 프리캐스트 콘크리트 승강장의 정보모델링
}

\section{Information Modeling for BIM Based Design of Precast Concrete Platform}

\author{
정지숙 ${ }^{1)}$, 이광명 ${ }^{2)}$, 박기현 ${ }^{3)}$, 박영식 ${ }^{4}$ \\ Jeong, Ji-Sook ${ }^{1)} \cdot$ Lee, Kwang-Myong ${ }^{2)} \cdot$ Park, Ki-Hyun ${ }^{3)}$ • Park, Young-Shik ${ }^{4)}$ \\ Received February 21, 2014 / Accepted February 28, 2014
}

\begin{abstract}
The construction method using PC(Precast Concrete) has been widely used because the method can shorten the construction period and improve construction quality. In this paper, through the analysis of present design process for PC railway platform, design parameters on the geometry and properties were extracted and 3D information models for PC railway platform were constructed by the parametric modeling technique. Furthermore, the interface module was developed to link 3D models to the structural analysis/design sheet and database program using VBA(Visual Basic Application). This information model could be used in various areas including structural analysis and design, 2D drawing, quantity estimation and 4D simulation including clash detection.
\end{abstract}

KEYWORDS: BIM, Information Modeling, Parametric Modeling, Platform, Structural Analysis/Design Sheet, Database

키워드: BIM, 정보모델링, 파라메트릭 모델링, 승강장, 구조계산서, 데이터베이스

\section{1. 서론}

\section{1 연구 배경}

IT의 발전과 함께, 최근 건설 산업에서도 생산성 향상을 목적 으로 구조설계방법이 2D CAD 기반에서 3D BIM(Building Information Modeling) 기반으로 변화하고 있다. BIM 기술은 설계 초기에서부터 건설 정보의 통합을 요구하여 하나의 공유된 모델 을 기반으로 하기 때문에, $2 \mathrm{D}$ 모델을 이용한 설계에 비해 일관성 을 갖는다(Jo et al., 2012, Park et al., 2012). BIM은 건설 프로젝 트의 라이프사이클 동안에 발생하는 문제들을 사전에 파악하고 신속하게 대응할 수 있도록 도움을 주며, 이러한 장점으로 인해 급속 시공이 필요한 PC(Precast Concrete) 구조물에도 BIM 기 술을 적용하려는 시도가 이루어지고 있다. 그러나 발주처 간 제 공되는 기준이 상이하고 그 자체도 원칙적이고 기본적인 수준에 서 정의되어 있어, 실무에 활용하기에는 미흡한 실정이다. 반면
미국의 경우에는 PCI(Precast/Prestressed Concrete Institute) 를 중심으로 $\mathrm{BIM}$ 기반의 시방서 및 설계기준을 정립하여 현장 검증 단계에 있다(Eastman et al., 2011).

\section{2 연구 목적 및 내용}

현재 일반적인 PC 부재 설계/제작 프로세스는 대부분 $2 \mathrm{D}$ 를 기반으로 하고 있으며 일방향적인 순서로 진행되고 있다. 더불 어 각 프로세스 별로 발생하는 정보들은 서로 연관성을 지니지 못하여 별개로 작업되고 있다(Kang, 2011). 본 논문에서는 PC 승강장의 BIM 기반 설계를 위한 정보모델 구축을 통해 승강장 구조물의 전 생애주기 동안의 정보가 원활히 교환되고 재사용이 가능하게 함으로써 구조해석 및 설계, 물량 산출, $4 \mathrm{D}$ simulation 등 다양한 분야에 정보 모델을 활용할 수 있도록 하였다.

먼저 PC 부재를 사용한 승강장의 설계 프로세스를 분석하여 이에 필요한 변수를 속성변수와 형상변수로 나누어 정의하고,

\footnotetext{
${ }^{1)}$ 학생회원, 성균관대학교 대학원 건설환경시스템공학과 석사과정 (anpim@skku.edu)

${ }^{2)}$ 정회원, 성균관대학교 대학원 건설환경시스템공학과 교수, 공학박사 (leekm79@skku.edu) (교신저자)

${ }^{3)}$ 정회원, 아이에스동서주식회사, 책임연구원 (kihypark@isdongseo.co.kr)

${ }^{4)}$ 정회원, 아이에스동서주식회사, 연구소장, 공학박사 (210039@isdongseo.co.kr)
} 
변수 간의 치수 제약조건 및 형상 제약조건을 선정하였다. 이러 한 구속조건에 근거하여 파라메트릭 디자인 방법론을 적용한 $3 \mathrm{D}$ 모델을 구축하였다. 다음으로 모델의 파라미터를 라이브러 리화하여 Excel로 정보를 추출하였으며 이를 구조계산서 및 Access 프로그램과 연동하여 설계변경에 따른 형상의 변화를 시각적으로 확인할 수 있음은 물론 발생되는 모든 정보를 체계 적으로 관리할 수 있도록 하였다. 이를 기반으로 리모델링 및 신설 승강장 구조물에 적용 가능한 PC 구조물의 BIM 기반 정보 모델을 구축하였다.

\section{2. 프리캐스트 콘크리트 승강장}

최근 공기 단축을 위하여 건설 전 분야에 PC 공법의 사용이 증가하고 있으며, 철도 역사의 경우에도 이를 사용하여 승강장 을 신설하거나 재건축하는 사례가 증가하고 있다. 그러나 PC 승강장의 경우 공사비가 현장 타설 방식에 비해 최소 2 배에서 최대 4배까지 증가하기 때문에 활성화가 어려운 실정이다.

그러나 PC 승강장은 기존 열차 운행 노선에서 철거가 불가능 한 철탑 및 구조물의 훼손 없이 공사가 가능하며, 선 제작을 통한 공기단축이 가능하기 때문에 공사비 증액의 부담에도 불구하고 적용되고 있다. 또한 승강장의 노후화로 인해 재건축이 증가하 고 있는 시점에서, $\mathrm{PC}$ 를 활용한 승강장의 건설은 점차 증가할 것이고 그에 따라 철도 정거장 신설 및 재건축에 적용 가능한 경제성 있는 승강장 시공법 개발을 위해 PC 승강장의 BIM 기반 설계 및 시공이 필요하게 될 것으로 판단된다.

승강장의 기본 형상은 Figure 1과 같이 줄기초, 피어, 슬래브, 지붕으로 구성되며 지붕을 제외한 세 부분이 구조물에 해당하고 이를 표준 모듈로 정하였다. 구조물의 기준이 되는 슬래브의 지 간 길이는 지붕 기둥 간격을 기준으로 $6 \mathrm{~m}$ 혹은 $8 \mathrm{~m}$ 로 제작되며, 도로 적재용량 제한에 따라 삼 분절로 나누어 제작된다. 피어는 기둥과 보를 결합한 형식으로 파이형 형상이며, 이러한 피어와 슬래브는 공장에서 선 제작되어 현장에서 쉽고 빠르게 시공된

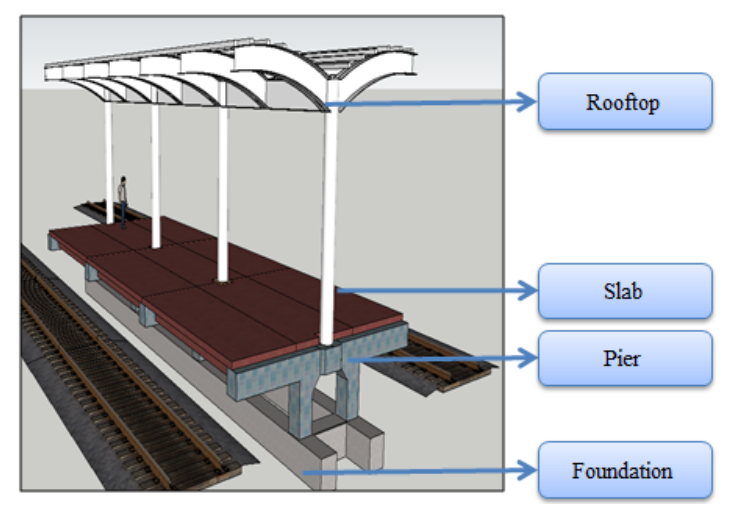

Figure 1 Basic Shape of PC Platform
다. 기초는 부등침하를 방지하기 위하여 다른 모듈과 달리 현장 타설 방식을 적용한다.

\section{3. 승강장의 BIM 기반 모델링}

\section{1 프리캐스트 콘크리트 승강장의 설계 프로세스}

$\mathrm{PC}$ 승강장의 설계 프로세스는 다음과 같다. 먼저 표준 모듈 인 슬래브, 피어, 기초의 단면 제원 및 두께를 가정한다. 다음으 로 구조계를 결정하고 하중을 산정하여 조합하는 구조해석을 진행하게 된다. 일반적으로 상용 프로그램을 사용하며, 승강장 의 경우에는 자중, 군중 활하중, 열차 풍하중, 군중 혼잡하중 등 을 고려하게 된다. 그리고 계산된 설계 하중을 Excel 형식으로 작성된 구조계산서에 입력하여 최대 단면력을 구하게 되는데, 이 때 파이형 피어의 경우에는 두 개의 기둥부와 한 개의 보로 나누어 세부적으로 계산한다. 계산된 단면력을 구조해석 결과와 비교하게 되며 추가로 철근비 계산을 통하여 최대 철근비의 초 과 여부 등을 검토한다. 더불어 본 PC 구조물은 피어와 줄기초 를 PS강봉으로 연결하기 때문에 지점부의 긴장력 및 지압 응력 검토가 추가로 이루어져야 한다. 이러한 일련의 과정은 일반 PC 부재와 같이 여러 번의 반복 작업을 통하여 수정되며 최종 단계 에 이르게 된다(Olofsson et al., 2008).

\section{2 프리캐스트 콘크리트 승강장의 PBS 및 구속조건}

승강장 구조물에 사용되는 설계변수는 크게 속성변수와 형상 변수로 분류할 수 있다. 먼저 속성변수란 부재의 물성치와 하중 에 관련된 변수로 콘크리트 및 철근의 강도, 탄성계수, 지지 지반 의 단위중량, 내부 마찰각, 표준관입 시험치, 단위하중 등이다. 다음으로 형상변수는 표준 모듈 단면을 정의하는데 필요한 수치 로서 폭과 높이, 헌치 부의 길이 등을 포함한다. 이를 기반으로 Figure 2와 같이 PBS(Product Breakdown Structure)를 작성하였다.

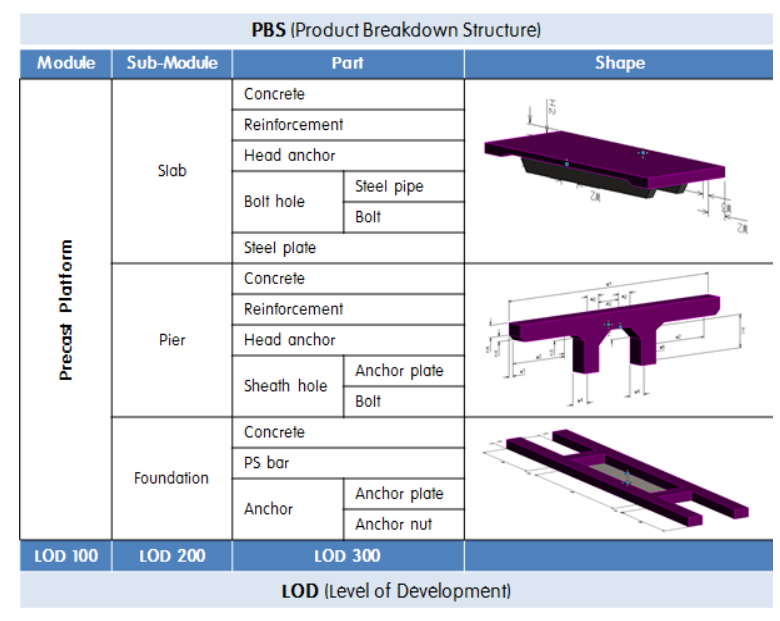

Figure 2 PBS of PC Platform 
이렇게 단면을 표현하는 데에는 콘크리트를 기준으로 슬래브 에서 8 개, 피어 13 개, 줄기초 6 개 총 27 개의 형상변수가 필요하 다. 그 중 유지관리 및 작업의 용이성을 위해 일부 헌치 부의 경사를 1:1로 고정하고 모듈 간의 조립관계를 고려하면 총 7 개의 변수가 서로 구속조건을 지니고 있어 결과적으로는 20 개의 변 수만으로 승강장의 단면을 표현할 수 있으며 이를 Figure 3에 나타내었다.

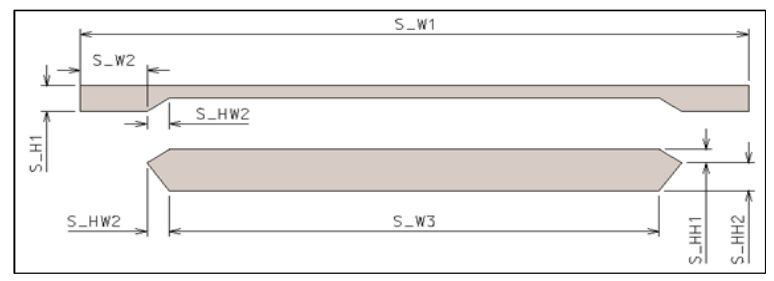

(a) Parameters of Slab

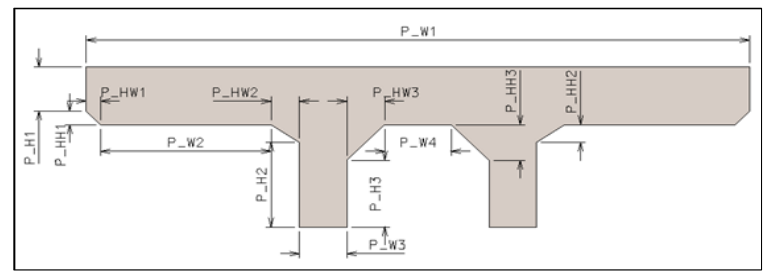

(b) Parameters of Pier

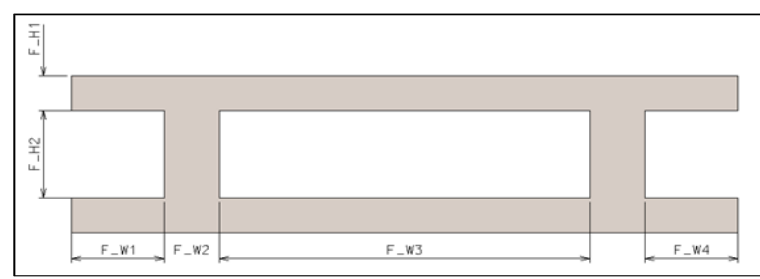

(c) Parameters of Foundation

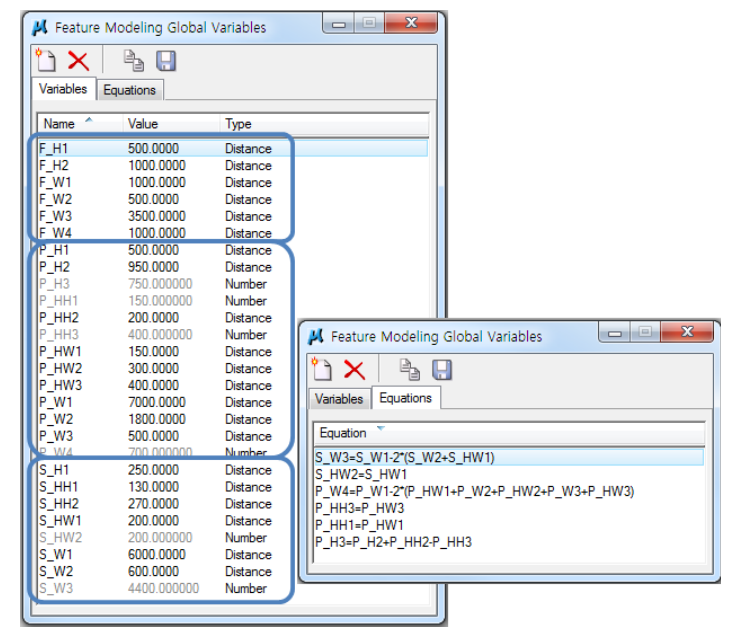

(d) Constraint Condition

Figure 3 Parameters and Constraint Conditions

\section{3 프리캐스트 콘크리트 승강장의 파라메트릭 모델링}

3.2절에서 선정한 설계변수와 구속조건을 바탕으로 파라메 트릭 디자인 방법론을 적용하여 $3 \mathrm{D}$ 모델링을 수행하였다. 모델 링을 수행하기 전, 모델의 상세 모델링 기준인 $\mathrm{LOD}($ Level of Detail/Development)를 300 수준으로 정의하였으며 이는 볼트 와 너트 등을 포함하는 파트 단위의 수준이다.

파라메트릭 모델링을 통한 $3 \mathrm{D}$ 객체 형상은 기본적으로 두 가지 단계로 이루어진다. 먼저 각 서브 모듈 별로 파라메트릭 단면을 작성한다. 이 후 각 단면의 두께를 지정하고, 서브 모듈 간의 중심축을 맞추고 접합부를 설정하는데 있어 필요한 구속조 건을 고려하여 3 차원 객체를 만들게 된다. 이러한 단계는 Microstation V8i의 DDDesign (Dimension Driven Design) 기 능과 Feature Modeling 기능을 사용하여 진행하였다.

각 단면의 변수는 다음의 Figure $4(\mathrm{a})$ 와 같은 인터페이스 창에 서 언제든지 수정 가능하며 임의의 값을 변경시킬 시 이와 연관 되어 있는 부재 길이 값들이 자동으로 갱신된다. 또한 각각의 파라메트릭 단면에 fix point를 설정하여 cell로 저장한다면 언제 든지 라이브러리로 재사용할 수 있으며 이를 통해서 객체의 생성

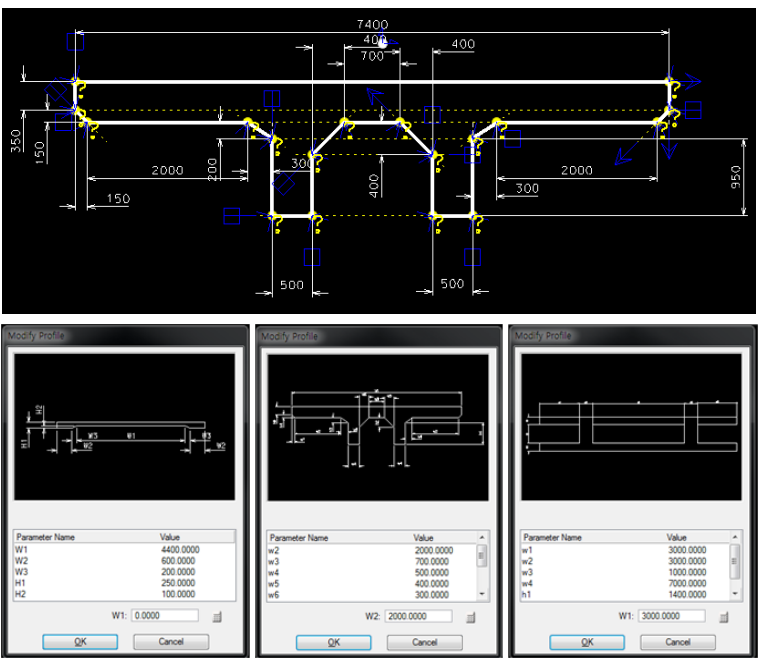

(a) Parametric Section and Interface

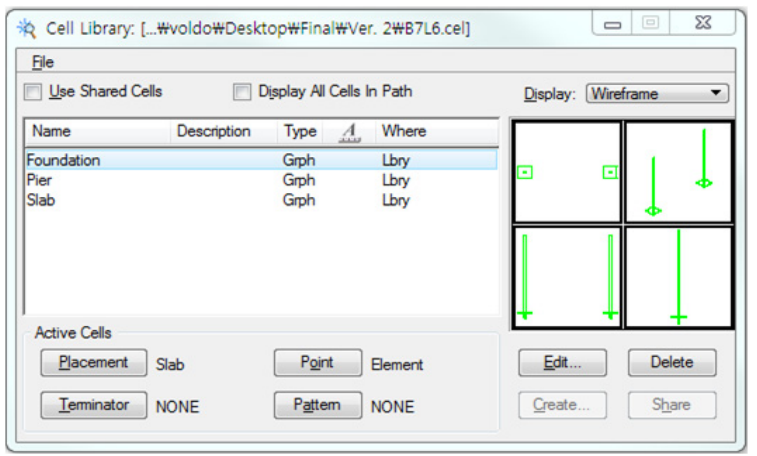

(b) Cell Library

Figure 4 Parametric Section 
및 수정을 용이하게 할 수 있다. 이는 설계 변경 시 형상의 크기 및 개수를 조절하여 능동적이고 효율적인 모델링이 가능하게 한다.

\section{4. 승강장의 정보모델 구축 및 활용}

\section{1 정보모델 구축 계획}

3장에서 승강장을 구성하는 모듈을 정의하고 분류체계를 작 성하였으며, 이를 통하여 형상 및 속성정보, 구속조건 등의 정보 를 정리하였다. 이렇게 정리된 정보들을 다른 프로그램으로 추 출 및 교환 가능하게 하고 간편하게 사용하기 위하여 Figure 5 와 같이 정보 교환의 흐름을 도식화하였다.

먼저 강도, 탄성계수 등을 포함하는 속성정보와 작업공정, 설 계정보와 같은 사항을 Excel 구조계산 시트에 저장하였으며 여 기에 Microstation에서 구축한 3D 모델의 형상정보를 CSV(comma Separated Value) 포맷으로 변환하여 Excel에서 사용할 수 있 도록 코딩하였다. 이렇게 통합된 정보들을 Microsoft Access와 연동시켜 데이터베이스화하였다. 이와 같은 방식으로 구축된 정 보모델은 물량산출 및 $4 \mathrm{D}$ simulation 등을 가능케 한다(Alfares and seireg, 1996).

\section{2 구조계산서 연동 모듈}

프리캐스트 콘크리트 승강장의 정보모델을 활용하는 방안의 첫 번째로, 구조계산서 연동 모듈을 구축하였다. 이는 단면력 계산 등의 단순 반복 작업을 용이하게 하며 재설계에 따른 모델 의 변화를 실시간으로 검토할 수 있도록 해준다. 이의 첫 단계로 Excel 형식의 구조계산서와 $3 \mathrm{D}$ 파라메트릭 모델을 연동하였다. 따라서 모델 라이브러리 내의 형상정보 등을 구조 계산에 필요 한 값들로 활용하여 경제성을 검토하거나 설계 타당성을 평가하 는데 활용할 수 있다.

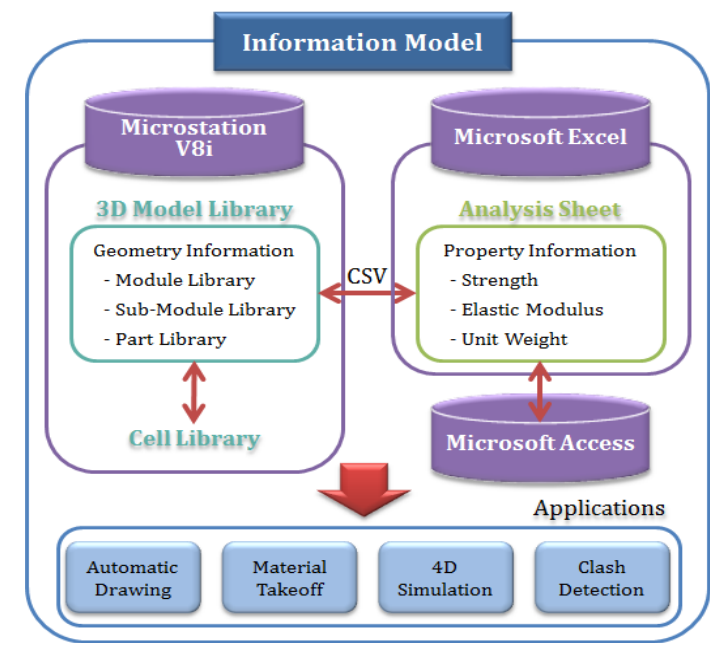

Figure 5 Information Flow
이를 위해서는 Microstation의 parametric set table menu를 사용하여 저장된 파라미터 중 필요한 값만을 CSV 확장자로 export 하였고, 그 후 원하는 양식대로 excel에서 import하였다. 이렇게 형상치수를 추출한 후에 VBA(Visusal Basic Application)을 활용 하여 속성변수 등을 직접 입력할 수 있는 인터페이스를 개발하 였다. 모듈이 진행되는 동안 사용자가 인터페이스를 통하여 입 력하거나 CSV에서 불러온 변수들이 코딩을 통해 자동으로 구조 계산 시트에 연결되며, 모듈이 종료되면 결과 창에 단면력 등의 구조계산 결과가 출력된다.

이렇게 개발된 모듈은 $3 \mathrm{D}$ 정보모델과 설계정보를 연동해줄 뿐만 아니라 설계자가 보다 손쉽게 변수를 다룰 수 있도록 GUI 에 기반을 두어 재설계가 용이하도록 도와준다. Figure 6은 필요 한 형상변수를 추출한 상태를 나타내며 Figure 7은 인터페이스

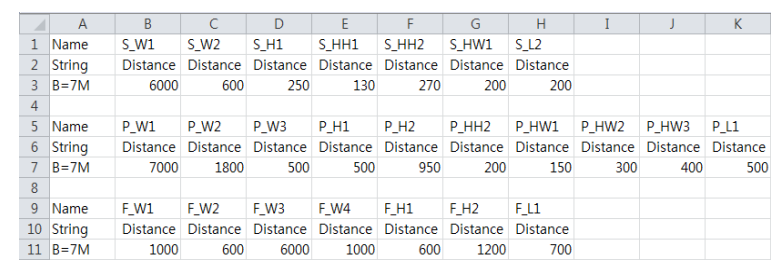

Figure 6 Exported Parameters

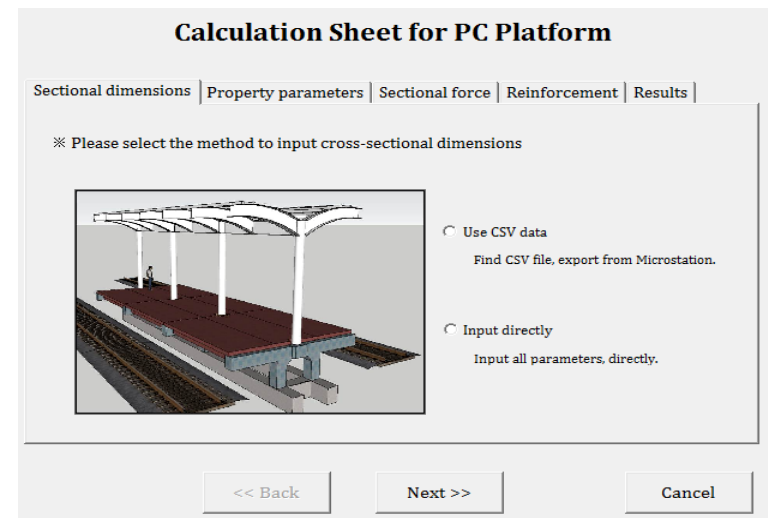

(a) Sectional Dimensions

Calculation Sheet for PC Platform

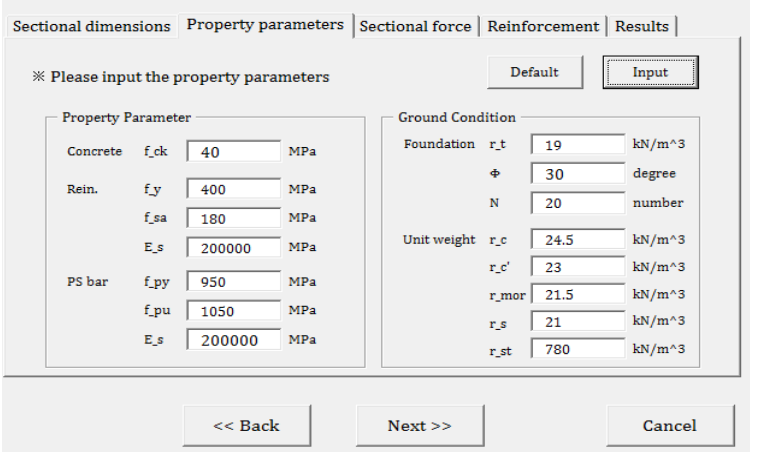

(b) Property Parameters

Figure 7 Exported Parameters 


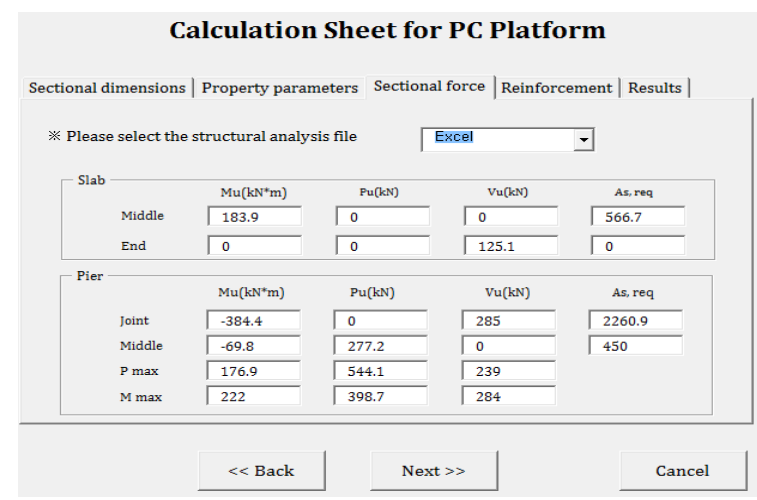

(c) Sectional Forces

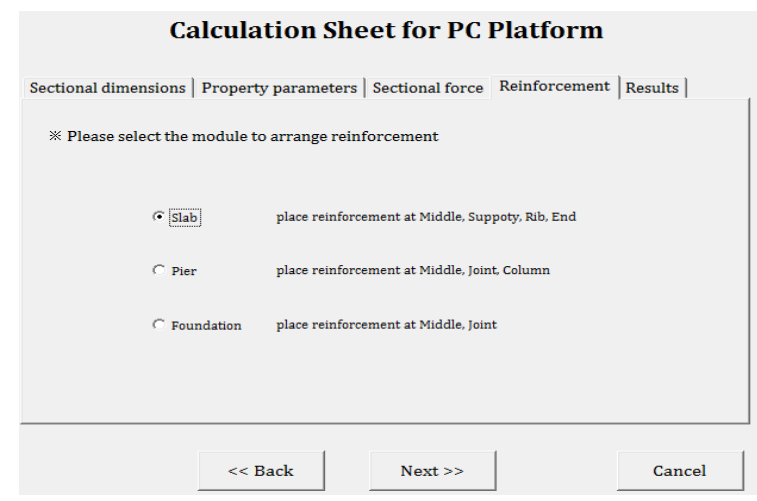

(d) Reinforcements

Calculation Sheet for PC Platform

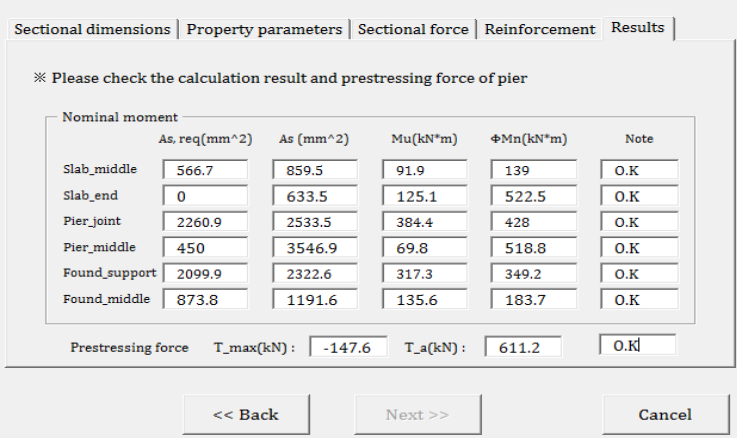

(e) Results

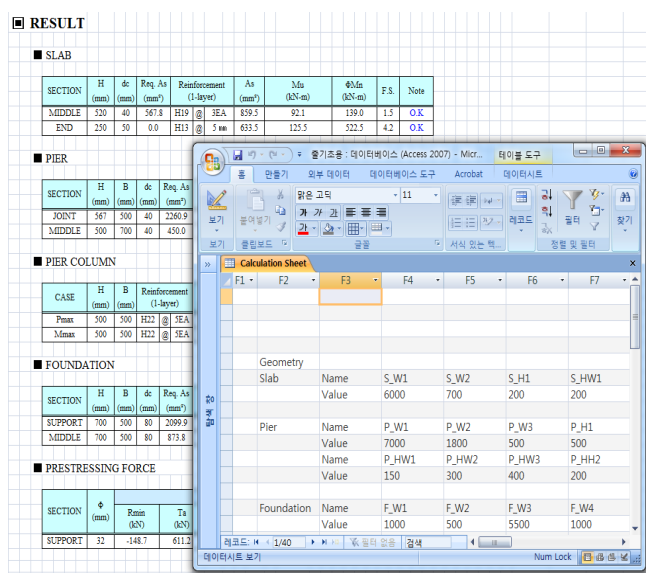

(f) Calculation/Analysis Sheet

Figure 7 Exported Parameters (continue)
가 진행되는 과정을 나타낸다. 먼저 형상변수 입력을 통하여 단 면을 가정하고 부재 물성치 등의 속성변수를 입력한다. 이 때 형상변수의 경우에는 'input directly' 버튼을 통하여 각 변수를 직접 타이핑할 수도 있지만 'Use CSV data' 버튼을 통하여 Microstation에서 추출한 모델의 형상변수를 불러올 수도 있다. 다음으로 Figure 7(c)의 창에서 구조해석 결과를 불러오고, 계산 된 필요 철근량에 근거하여 이어지는 창에서 슬래브, 피어 줄기 초에 대해 철근을 배치하게 된다. 배근까지의 모든 과정이 종료 되면 Figure $7(\mathrm{e})$ 의 결과 창에서 철근량, 공칭모멘트 등의 확인 을 통하여 설계 적합성을 판단할 수 있다. 이 모든 과정은 Figure 7(f)와 같이 Excel 및 Access와 연동되어 있기 때문에 데이터베 이스 형태로 관리 및 저장이 가능하다.

\section{3 철근 자동배근 모듈}

4.2절의 모듈을 사용함으로써 Microstation 3D 모델 라이브 러리의 정보와 Excel 구조계산 시트가 연동되며, 이를 활용하여 슬래브, 피어, 줄기초 각 서브 모듈에 대한 구조해석 및 설계가 가능하다. 그러나 줄기초의 경우에는 다른 서브 모듈과는 다르 게 현장타설 방식으로 시공된다. 따라서 현장 조건에 따라 그 형상치수가 쉽게 바뀔 수 있고, 이로 인한 재설계가 빈번히 발생 할 수 있기 때문에 줄기초에 대한 모듈을 추가로 구축하여 재설 계에 따른 $3 \mathrm{D}$ 모델의 변화를 시각적으로 확인하고, 자동으로 합리적인 양의 철근을 배치할 수 있도록 하였다.

본 모듈의 진행 순서는 Figure 8과 같이 두 단계로 진행된다. 먼저 구조 계산에 필요한 파라미터를 입력하게 되는데 이는 가 로, 폭, 높이의 형상수치와 콘크리트 및 철근의 강도, 피복두께 를 포함한다. 이 후 구조해석 결과로서 극한모멘트와 전단력을 입력하면, 이에 따른 필요 철근량이 계산되어 팝업창에 표시된 다. 다음은 철근과 관련된 창으로, 휨철근과 전단철근의 직경을 입력하게 된다. 이렇게 공칭 직경을 드롭다운 메뉴로 선택하고 Calculate 버튼을 누르게 되면 Arrangement 창에 휨철근의 개

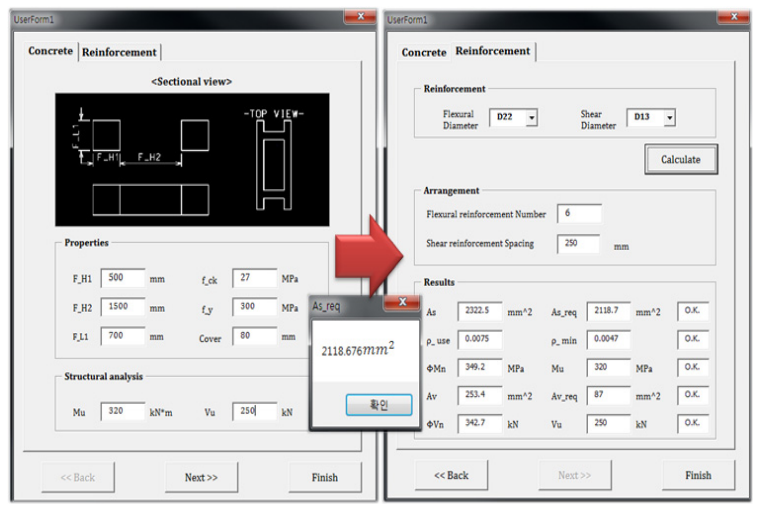

Figure 8 Process of Foundation Module 

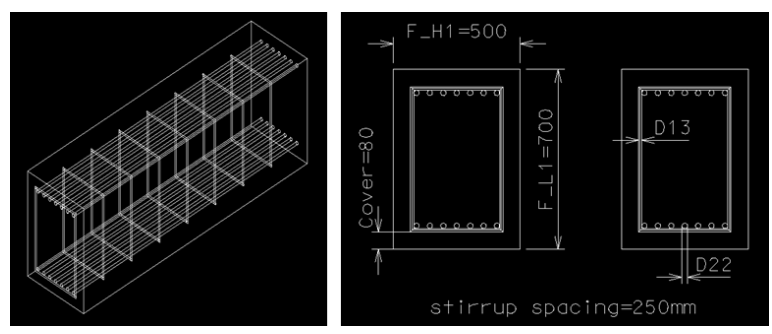

Figure $93 \mathrm{D}$ Model of Foundation and Sectional View

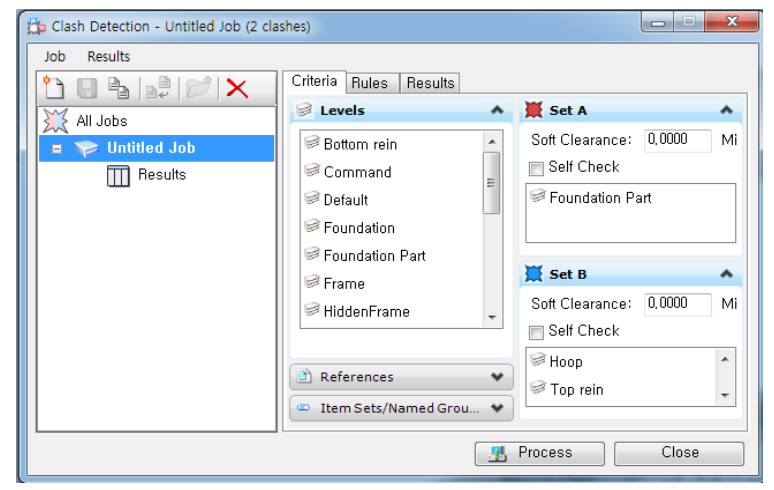

(a) Setup Screen of Navigator

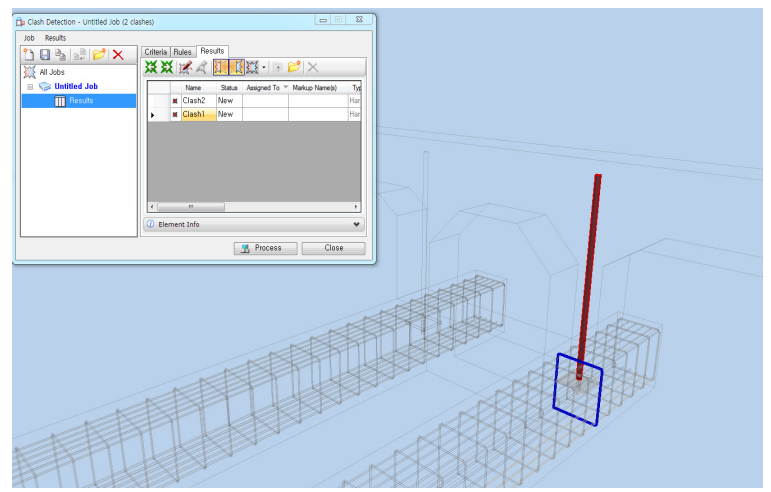

(b) Clash Detection

Figure 10 Clash Detection using Navigator
수 및 전단철근의 간격이 자동으로 계산되어 보여지며, Results 부분에 이에 따른 공칭모멘트 및 전단력 등이 계산된다. 만일 설계자가 조금 더 안전한 설계를 위하여 휨철근의 개수를 추가 하고 싶거나, 전단철근의 간격을 세밀하게 조정하고 싶다면, 해 당하는 Textbox의 수치를 바꾸어 입력하면 그에 따른 재계산 결과 값을 확인할 수 있다. 철근량 및 철근비 등의 모든 항목에서 O.K. 가 되면 Finish 버튼을 눌러 모듈을 종료할 수 있으며, 종료 시 자동으로 해당하는 형상 수치에 따른 $3 \mathrm{D}$ 모델이 생성된다. 이러한 모델의 단면에서는 스터럽의 간격, 피복두께 및 형상수 치를 확인할 수 있으며 이를 Figure 9에 나타내었다.

\section{4 간섭검토 및 4D Simulation}

전통적인 $2 \mathrm{D} \mathrm{CAD}$ 에서의 간섭 검토는 설계 도면들을 겹쳐 시각적으로 확인하거나, 발생할 것으로 예상되는 국소 부분에 대한 검토가 대부분을 차지하였다. 그러나 이 방법은 시간이 많 이 걸리고 따라서 많은 비용이 필요하며 검토 과정에서 오류가 발생할 확률이 높다. 그리고 대부분의 검토가 설계가 완료된 후, 시공 직전에 수행되기 때문에 최신 도면을 필요로 하며, 오류를 발견하고 그를 수정하기 까지 시간적 여유가 많지 않다(Eastman et al., 2008). 따라서 본 연구에서는 설계 단계에서 정보모델을 활용하여 사전에 간섭을 검토할 수 있도록 하였다. 프로그램은 Bently사에서 제공하는 Navigator를 사용하였다.

Figure 10은 Navigator를 사용하는 화면이다. 본 모델의 경우 에는 슬래브와 피어가 모두 프리캐스트 제품이므로 이는 제외하 고, 현장 타설 방식으로 시공되는 줄기초의 휨철근 및 전단철근 과 슬래브의 부품인 PS강봉 사이의 간섭만을 Figure 10(b)와 같이 검토하였다.

또한 Microstation V8i의 Animation Producer Dialog 기능을 이용하여 Figure 11과 같이 $4 \mathrm{D}$ simulation을 위한 공정표를 작성

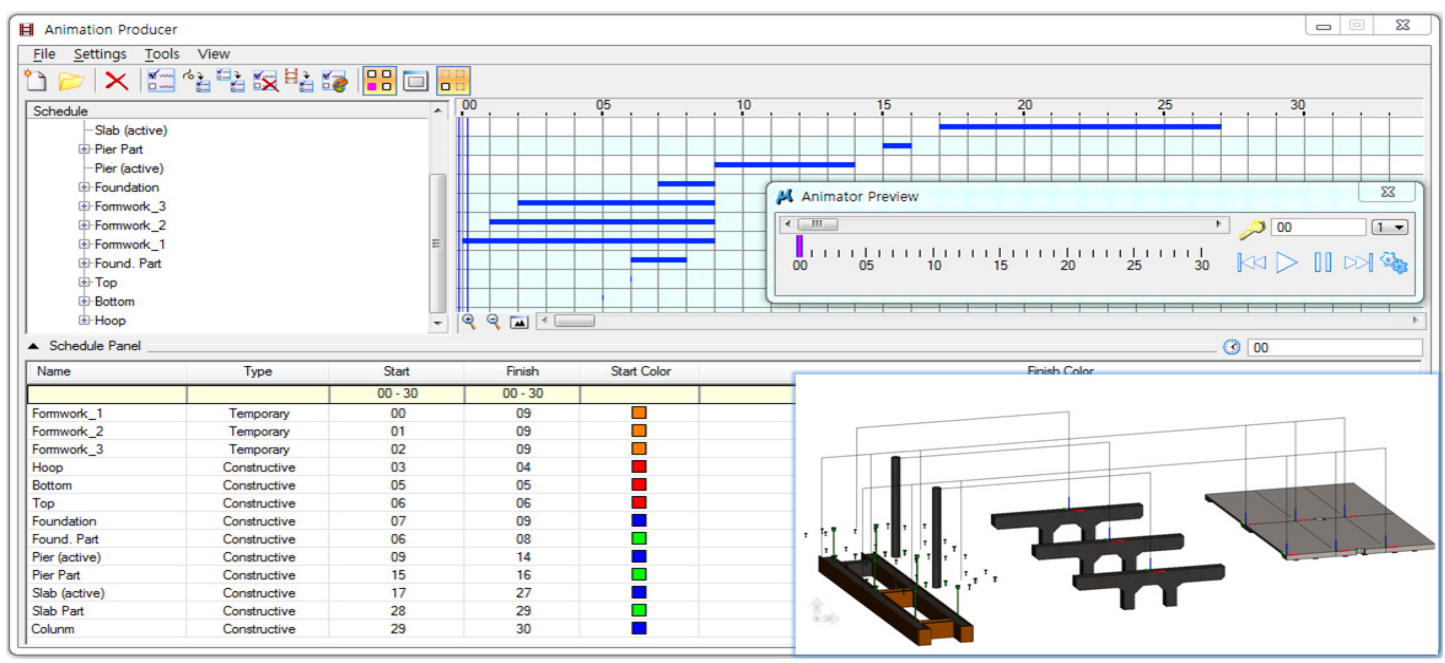

Figure 11 4D Simulation 
하였다. 먼저 작업 단위의 Time Schedule을 작성하고 각각의 작업 단위에 해당하는 $3 \mathrm{D}$ 모델 객체를 링크하였으며, 작업 타입 은 Constructive, Destructive, Permanent, Temporary로 구분 하여 지정하였다. 이렇게 제작된 $4 \mathrm{D}$ simulation은 공사 일정을 시각적으로 확인할 수 있게 도와주며, 시공성을 판단할 수 있는 자료가 된다. 또한 인터페이스에서 제작한 Time Schedule 표는 Ms Project나 Primavera 등의 공정관리 프로그램과 호환이 되 어 재사용이 가능하다.

\section{5. 결론}

본 논문에서는 철도 정거장 신설 및 재건축에 적용 가능한 PC 승장장 구조물을 대상으로 분류체계를 선정하고 정보모델 을 구축함으로써 설계 프로세스의 효율성을 증진시킬 수 있는 방안을 제시하였다. 이 연구를 통해 도출된 주요 연구 결과를 요약하면 다음과 같다.

(1) PC 승강장의 BIM 기반 설계를 위한 정보모델을 구축하기 위하여 분류체계를 작성하고 파라메트릭 모델링을 수행하 였다.

(2) PC 승강장의 설계 프로세스를 분석하여 GUI 기반의 설계 모듈을 개발하였으며, 이를 구조계산서 및 $3 \mathrm{D}$ 파라메트릭 모델과 연동하여 설계 변경에 따른 모델의 변동성을 실시간 으로 검토할 수 있도록 하였다.

(3) 구축된 정보모델을 활용하여 PC 승강장의 구조계산 및 물 량 산출, 경제성 검토, 대안 선정 등이 가능할 것으로 판단된다.

(4) $4 \mathrm{D}$ simulation을 통하여 제작 공정의 이해도를 향상시키고 부재 간섭을 검토하여 사전에 설계 오류를 발견, 수정함으로 써 공기 단축 및 비용 절감을 기대할 수 있다.

\section{감사의 글}

본 연구는 국토교통부/국토교통과학기술진흥원 건설기술연 구사업의 연구비지원(10기술혁신B01-직선교량의 공사기간 단 축을 위한 표준모듈 활용 조립식교량 기술개발 연구단)에 의해 수행되었으며, 본 연구를 가능케 한 국토교통부 및 국토교통과 학기술진흥원에 감사드립니다.

\section{References}

Alfares, M and Seireg, A. (1996), "An integrated system for computer-aided design and construction of reinforced concrete buildings using modular forms", Automation in Construction, Vol. 5, No. 5, pp. 323-341.

Eastman, C., Aram, S. and Venugopal, M. (2011), "Status of Precast Project BIM Efforts in the US", PCI Conventional and National Bridge Conference.

Eastman, C., Teicholz, P., Sacks, R. and Liston, L. (2008), BIM HANDBOOK - A Guide to Building Information Modeling, John Wiley \& Sons, Inc.

Jeong, J-S, Lee, K-M, Park, K-H and Park, Y-S (2013), "BIM Based Design of Precast Concrete Plattorm”, Proceedings of ICCBEl 2013, pp. 367-369.

Jeong, J-S (2013), BIM Based Design of Precast Concrete Platform, Master Thesis, SungKyunKwan University.

Jo, J-H, Lee, K-M and Nam, S-H (2012), "Classification Scheme of Modular Bridge Pier for Information Modeling", Proceeding of society of CAD/CAM engineers, pp. 841-844.

Jo, J-H, Lee, K-M and Nam, S-H (2012), "Parametric Modeling of Modular Bridge Pier", KIBIM Annual Conference 2012, Vol. 2, No. 1, pp. 59-60.

Kang, T-W (2011), The Building Information Modeling Principle, Spacetime.

Olofsson, T., Lee, G. and Eastman, C. (2008), "Case studies of BIM adoption for precast concrete design by midsized structural engineering firms", ITcon, Vol. 13, pp. 303-323.

Park, N-Y, Jeong, J-S, Jo, J-H and Lee, K-M (2012), "Development of the RC Piers Design Module using Parametric Modeling Technique", KIBIM Annual Conference 2012, Vol. 2, No. 1, pp. 127-128.

Sacks, R., Eastman, C. and Lee, G. (2004), "Parametric 3D modeling in building construction with examples from precast concrete", Automation in Construction, V. 13, No. 3, pp. 291-312. 